\title{
The Geosystem Analysis of Exogenesis of High-Mountain Landscapes of the Basin of the River Girdymanchay in Azerbaijan
}

\author{
Ilham Mardanov, Agayev Tahir \\ Department of Physical Geography, Sumgait State University, Azerbaijan \\ Email: geography.sumqayit@mail.ru, aqayev_tahir@mail.ru
}

Received 12 October 2015; accepted 22 November 2015; published 25 November 2015

Copyright (C) 2015 by authors and Scientific Research Publishing Inc.

This work is licensed under the Creative Commons Attribution International License (CC BY).

http://creativecommons.org/licenses/by/4.0/

(c) †) Open Access

\begin{abstract}
For the geological systems, assessment of influencing exogenous relief forming processes having essential impact on development of landscape status arises need of development of various field and image interpretation methods for creation of scenarios of possible changes of a geo-ecological situation in various massif having harmful consequences, by identification of relationships of cause and effect. It was analyzed possibilities of prognosis of the changes of the geo-ecological situation in high-mountainous of Great Caucasus with use of the geological, geomorphologic, climate and landscape materials, data of digital processing of the photo images and visual observation. Also the possibilities of forecasting of change of landscape structure of highlands in natural area of Great Caucasus with use of various data were analyzed. It was defined the main differences of relief situation, hydro meteorological conditions in the various parts of high-mountainous geo systems in which exogenic processes were shown, character and intensity of land using which had the influence to the slope slides. These data allowed revealing the main distinctions of factors of a relief situation in which were shown exodynamic relief and landscape forming processes, character and intensity of the land use, to some extent influencing on descent of landslides and area of their destructive.
\end{abstract}

\section{Keywords}

Erosion, Exodynamic Process, Hydro Meteorological Process, Geodynamic Processes, Landscapes, Great Caucasus

\section{Introduction}

Problems of identification of the reasons of geodynamic processes—-taluses, scatterings and landslides—are

How to cite this paper: Mardanov, I. and Tahir, A. (2015) The Geosystem Analysis of Exogenesis of High-Mountain Landscapes of the Basin of the River Girdymanchay in Azerbaijan. International Journal of Geosciences, 6, 1254-1260.

http://dx.doi.org/10.4236/ijg.2015.611099 
many years in the center of attention of the geographical public of the country because of harmful consequences of these phenomena for the social sphere and economic activity of all mountain regions [1]-[3].

The southern and northeast slopes of the Great Caucasus differ the complex geomorphological structure which is showing in difficult structure of alternation of water-permeable layers of breeds, an interlacing of tectonic violations, and also the high seismicity which quite often is hardly noticeable, but a decisive factor of slipping and a collapse of mass of breeds.

The inclination of a terrestrial surface saving in considerable energy of all mass of breeds of a slope has essential impact on development of landslide processes. But, as we know, big biases of slopes do not always lead to landslides, even on sites close located to landslide massifs. So, slopes with strong maternal breeds are steady, slopes with alternation of layers of friable breeds and clays are the most subject to influence of geodynamic factors. Big biases of slopes, especially characteristic for the southern slope of Great Caucasus range lead to landslides of landslide character, in a root changing shape of a landscape of this site [4] [5].

On degree of resistance to impact of landslide processes in the territory of a massif active and steadier sites are differentiated. Within a mountain meadow zone steady sites in the landslide relation are characterized by existence of clearly expressed subalpine and Alpine landscapes [6]. Such sites can be subject to influence of others the exodynamic processes - to a soil erosion, accumulation and movement of taluses and the scatterings constituting not smaller danger to a landscape and all ecological situation [7] [8].

It is known that an important element of development of landscapes is the transfer of chemical particles as part of circulation of substances. In this regard mountain landscapes of Great Caucasus are low-studied and demand the analysis of impact of exogenous processes on changes of quantity and a ratio of various chemical elements and their connections in soils and vegetation depending on intensity of various natural phenomena.

\section{Objects and Methods of Their Researches}

The southeast tip of Greater Caucasus which is active from the point of view of a descent of landslides, always drew attention of researchers of various disciplines. The main landslide massifs, litological structure of breeds of landslide slopes, the basic landscape elements of separate large landslides were during this time defined.

These works were performed during field visual researches, and also the cameral researches meaning measurements on topographic maps, revealing the biases of a surface stimulating slipping of mountain masses.

Measurements of the cracks formed as a result of landslides on different massifs and definitions of their temporary dynamics allow to carry out in a certain degree territory division into districts on activity of breeds for the purpose of identification most of the landslides dangerous territories. The description of a landscape situation, its separate components promotes detection of the distinctions which were showed through a certain time occurring also under the influence of geodynamic processes.

Interpretation of space images gives the chance of them to interpretation for detection of geomorphological and landscape features of consequences of landslides both their spatial and temporary dynamics in the presence of pictures of different years [9]. In Azerbaijan many years were spent works on creation and improvement of various means and methods of interpretation of space data for definition of the directions of development of the harmful natural phenomena [10].

Digital models of a relief of the large landslide massifs located in the territory of research and covering some landscape zones allow to judge character of a geodynamic situation, substantially, influencing of exogenous relief forming processes [11] [12]. Studying these models received on the basis of processing a topographic map, the kept Google company as a result of transformation of space pictures, gives the chance to analyze communications between character of a relief, intensity of exogenesis and soil and landscape complexes within mountain and forest and mountain meadow zones of the Southern and Northeast slope of the Greater Caucasus.

In work the materials of space shootings received from various satellites in the 2012-2013 years on the basis of application of the processing programs SASPlanet, ArcGiS 10.2.1, the scanned large-scale maps and the cards subjected to a georeference, and also, the Google Landscape card were used.

Space pictures and the cards received by means of the ArcGíS program were subjected to a georeference in coordinate system and to projections.

In work the coordinate WGS_1984 system (World Geodetic System 1984) and a projection of UTM (Universal Transverse Mercator) which were given to WGS_1984_UTM_Zone_39N projection were used. Here 39N points to zone number in UTM projection, and N (Nothern Hemisphere)—on the northern hemisphere. The 
western border of the 39th zone passes on a meridian of $480 \mathrm{EL}$, and the eastern frontier passes on a meridian of $540 \mathrm{EL}$. This zone is chosen for the reason that in its limits the territory of researches is located.

In space pictures landslide zones and their territories were clearly looked through were delineated by means of the ArcGIS program enough, the horizontals uniting points with identical absolute height, were carried out through each 20 meters. By means of the 3D Analyst module of the ArcGís program TiN model (triangulated irregular network) of the territory was constructed. With use of the TiN to Raster tool of the 3D Analyst module the model TiN was transformed to the Raster type. Raster was transferred to a 3D format and to it the color gradation on height was applied.

During works images in landslide massifs and horizontals in a 3D format which were imposed on Raster were created. Separate fragments of space images were photographed by means of the Screenshot tool.

The materials of numerous researches of an environment of Greater Caucasus available in existence can give the chance to reveal prerequisites of emergence and development of landslide processes and to create a certain group of landslide massifs for the purpose of development of protective measures on prevention of their harmful consequences [13] [14]. The material on physiographic and synoptic division into districts of natural area of the Great Caucasus within Azerbaijan was for this purpose processed and a number of the factors causing a descent of landslide masses is defined.

The Khimran landslide stream begins on the left coast of Girdimanchay on a slope of a northern exposition of ridge Niyaldag, at the absolute height of $2100 \mathrm{~m}$ (Figure 1).

It is stretched at distance of $4 \mathrm{~km}$ to a valley of Girdimanchay and stops the activity at the height of $1200 \mathrm{~m}$. Its width on an amphitheater and in a transitional zone once made $20-100 \mathrm{~m}$, and on a carrying out cone-2.5 $3.0 \mathrm{~km}$, but recently considerably extended. The landslide stream the landslide materials narrowed the bed of the river Girdymanchay to 3 - 5 meters. Apparently from a space picture of the Google company, only the sites adjacent to an amphitheater of a landslide settle down within a mountain meadow zone, and the considerable part of landslide weight is in a mountain and forest zone of the Southeast spur of Main Caucasus Range. It in strong degree complicates landscape structure of this landslide, differing the high steepness of the surface reflected in its digital model (Figure 2).

Mountain meadow and subnival-nival zones which are in difficult environment, are characterized by a peculiar manifestation of altitudinal zonality within a zone. Unlike other landscape belts of Greater Caucasus, mountain meadows and rocky nival territories are remote territories, and because of it implementation of field researches

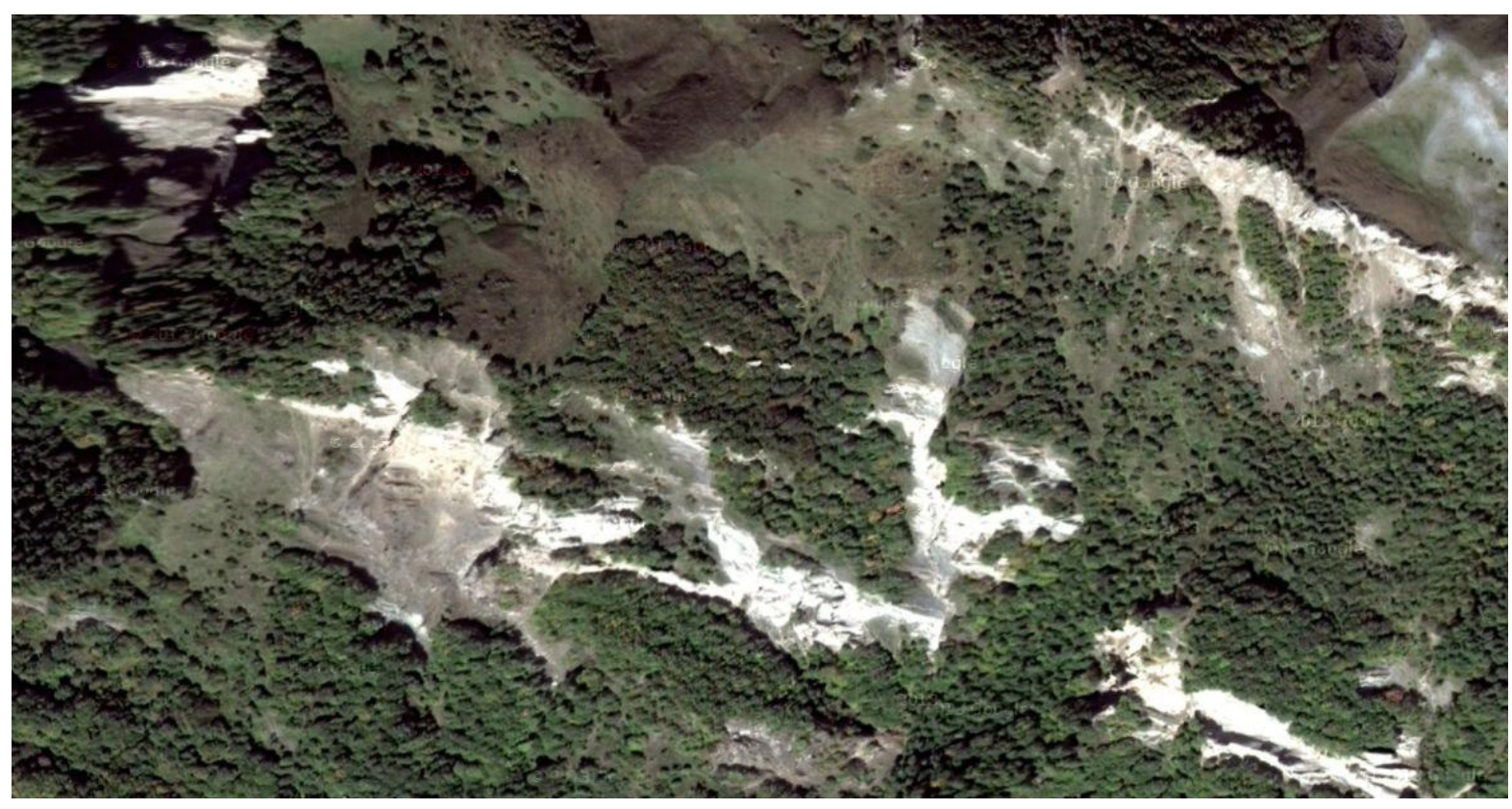

Figure 1. The space picture of the Google company (USA) photographed on September 29th of the 2012th year, with permission degree in $1 \mathrm{~m}$ on which the territory of the Khimran landslide stream with separate spots of forest and meadow sites is represented. 


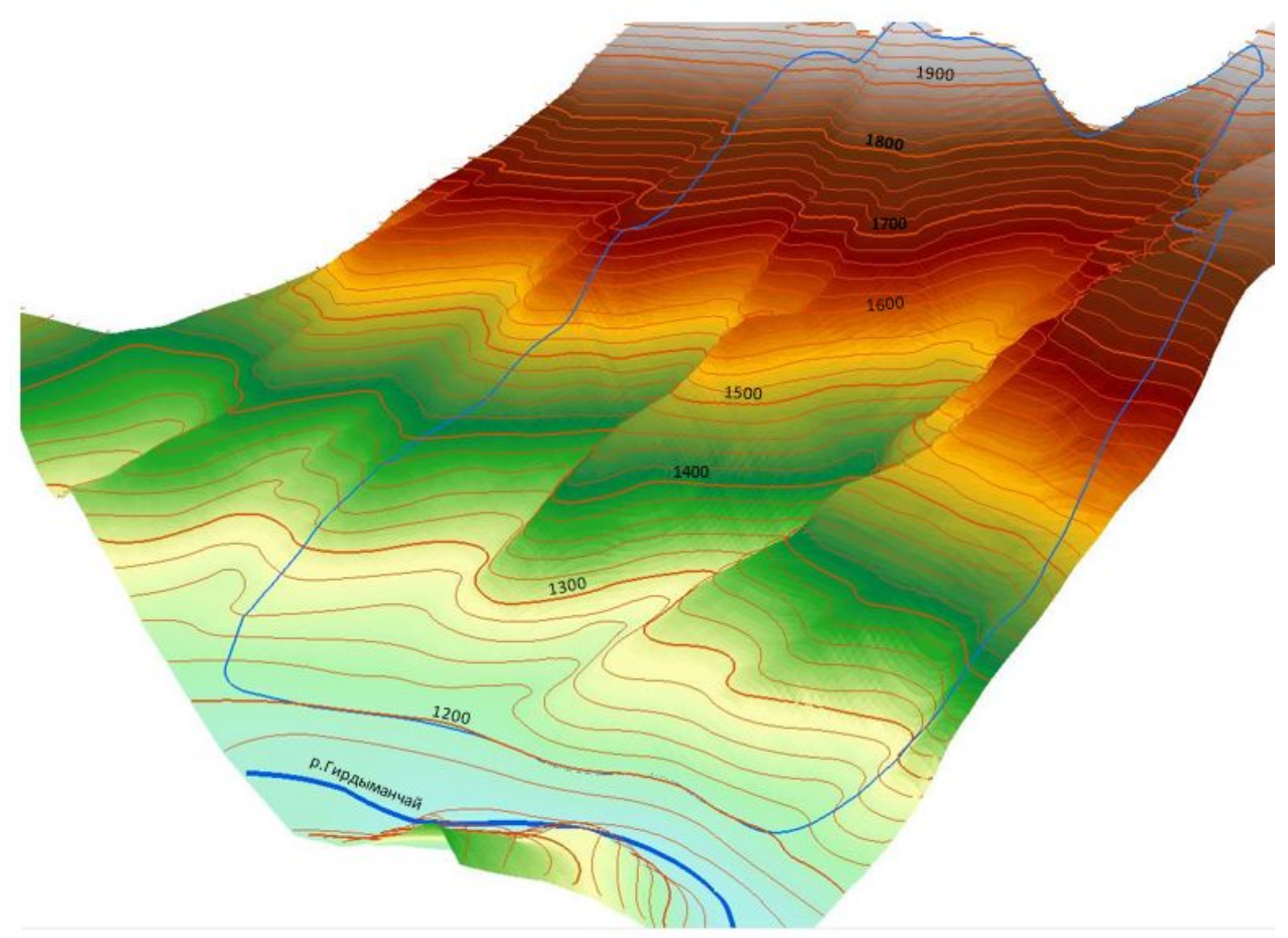

Figure 2. Digital model of a relief of the Khimran landslide stream for which the big steepness and a longitudinal dismembering of a surface is characteristic.

in these zones experiences certain restrictions. For this reason, the interpretation of large-scale aerial photographs where the main indicator sign is photo tone clarification in process of erodibility, can be considered creation of the three-dimensional digital models reflecting degree of exogenesis at researches of destruction of a soil cover of this territory under the influence of various processes in very effective ways.

It is necessary to emphasize very important methodical feature. At a visual interpretation of a condition of a soil cover of a mountain meadow landscape zone of Great Caucasus the most effective are the pictures photographed in summer months when the favorable vegetative conditions, allowing to allocate sites of different degree of an lighting of the photo tone which is an indicator of various projective covering vegetation are observed. In the pictures photographed in cold part of year, these distinctions because of a poor development of vegetation, high moisture content of a surface, existence of snow cover on slopes are leveled and don't reflect a real landscape and ecological situation.

During researches joint processing materials of an interpretation of the aerial photographs photographed in various years with topographic maps was provided.

By results of the carried-out researches it was revealed that important factors of development of geodynamic processes is the structure of spreading breeds which are rather pliable to erosive and denudation processes, especially in the conditions of showers, characteristic for mountain territories. The analysis of samples of soil profiles showed distinctions of their thickness depending on the biases of a surface causing extent of development of the degradation processes. These materials provide can give rather full information on types of soils, vegetable groups of mountain meadows of this territory, indicators of temperatures and the atmospheric precipitation influencing development of a soil cover, a territory relief, features of litological composition of rocks, volume of the river deposits which are result of an erosion.

Drawing up the cartographic materials reflecting influence of the degradation processes on mountain meadow 
soils and their state in different years and processes of exogenesis in a subnival-nival zone on the basis of accumulated knowledge, experience and use of the interpretation signs allows to estimate rather objectively intensity of these processes in time and space (Figure 3).

For this purpose in mountain meadow and subnival-nival zones:

1) Continuous snow places;

2) Snow places with exits of breeds;

3) Strong dismembered slopes of a subnival zone with exits of rocky breeds, taluses and with languages of snow places;

4) Strong dismembered slopes of a subnival zone with exits of rocky breeds and taluses;

5) The languages of snow places covering slopes of rocks;

6) Smoothed slopes of a subnival zone, in places covered with spots of snow places characteristic key sites, in different degree subject degradations, to physical aeration and a denudation were chosen.

These sites captured large mountain massifs in the central part of the Southern slope of Main Caucasus Range, in the Southeast slope of Great Caucasus Range, in a river basin of Girdymanchay, on the Northeast slope of Great Caucasus in basins of the rivers Gudialchay and Gusarchay. On these massifs distinctions in mutually influence of the natural and anthropogenous factors, connected are observed in the first stage, various degree of dismembering of the surface, bringing to differentiation of biases of a surface. At local level of a schematic map of separate sites on the scale of 1:25000, and at regional level the schematic map of all studied territory on the scale of 1:100000 is able to characterize these processes.

\section{Conclusions}

The numerous researches directed on development of actions for prevention of a descent of landslides are based on the purposes of reduction of biases of hillsides, the python ameliorative works meaning restoration of a close

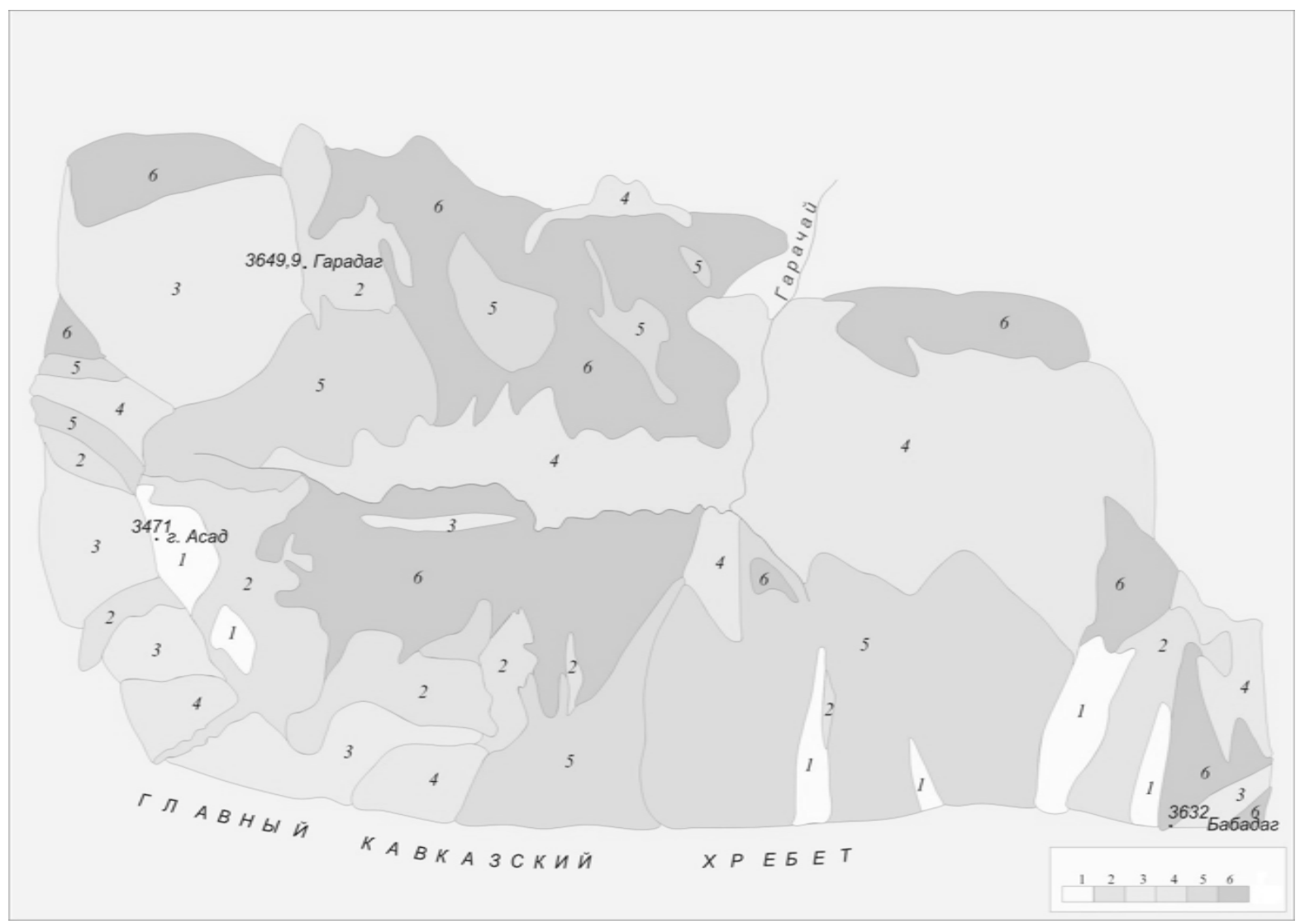

Figure 3. Schematic map of a subnival-nival zone round tops Asad (3471.0 m), Garadag (3649.9 m), Babadag (3632 m) in basins of the rivers Girdymanchay and Garachay. 
vegetable cover on broken massifs [9]. Such approach proceeds from insufficient understanding of an essence of the mechanism of this process covering not simply terrestrial surface, but rather powerful cover of sedimentary breeds with a certain stratification, sometimes some tens meters. Quite often in publications of various character expression "sliding of soils" that proceeds from misunderstanding of a geological and geomorphological essence of landslide process, the superficial relation to possible consequences of this phenomenon meets.

At the same time, attempts of melioration of landslide massifs which are ineffective are made. They are generally directed on alignment of a surface and restoration of a close soil and vegetable cover, including, by implementation a forest plantation.

These measures lead to temporary stabilization of a geodynamic situation that actually, is the beginning of a new cycle in development of landslide process [15]. Planting of trees improves soil and ecological, but not a geological and geomorphological situation as roots of trees aren't capable to constrain movement of mass of breeds sufficiently. Numerous landslides within a mountain and forest belt of Greater Caucasus within Azerbaijan, strongly changed all shape of a landscape can serve as an example, introducing before not meeting elements in its horizontal structure.

\section{Assumed Measurement}

In this regard there is an urgent need in large-scale inventory of mountain massifs taking into account the changing geomorphologic and landscape changes, meaning drawing up detailed landscape, geological and geomorphologic, soil and geobotanical map-scheme, including, with use of materials of space shooting [16]-[21]. Cartographic materials have to be added with the meteorological data including information on an annual course of air temperature, quantity, character and a mode of loss of a precipitation, average annual and average monthly air temperatures.

In the description of the landslide massif information on a humanitarian and economic situation of the landslide site, including data on number of settlements, number of their population, type of the settlement, features of their arrangement, quantity and character of the enterprises, the social objects located in this territory has to take an important place.

Accumulation and processing of large volume of data is able to afford to carry out comparison of the probable factors causing process of a descent of landslides and to reveal the key factor which hasn't been considered by initial consideration, for the purpose of search of opportunities of its neutralization. Such approach is capable to give bigger economic effect, than implementation of a number of the actions which sometimes aren't yielding desirable result.

\section{References}

[1] Alizade, E.K., Guliyeva, S.Yu. and Tarikhazer, S.A. (2005) Otsenka stepeni podverjennosti geokompleksov Yujnogo sklona Bolshogo Kavkaza opolznevimi protsessami. In: Nauchno-prakticheskaya konferentsiya, Prirodno-razrushitelniye yavleniya Sheki-Zakatalskoy oblasti i ekogeograficheskiye problemi razvitiya regiona, Sheki, 9-10 Iyunya 2005, 63-65.

[2] Pashayev, N.A. (2007) Upravlenie prirodnix katastrof na territorii Azerbaydjanskoy respubliki. In: Trudi Geograficheskogo obshestva Azerbaydjana. Sovremenniye geograficheskie issledovaniya v Azerbaydjane, Tom XI, Baku, 283289.

[3] Djurović, P. (2012) The Debeli Namet Glacier (Durmitor, Montenegro)—From the Second Half of the 20th Century to the Present. Acta Geographica Slovenica, 52, 277-301. http://dx.doi.org/10.3986/AGS52201

[4] Mardanov, I.I. (2009) O vozmojnosti ispolzovaniya ekspertnoy sistemi dlya prognozirovaniya opolzney. In: Trudi geograficheskogo obshestva Azerbaydjana, Tom XIV, Geograficheskiye problemi obespecheniya ekologicheskoy bezopasnosti prirodno-xozyaystvennix sistem, Baku, 36-40.

[5] Mardanov, I.I. (2011) Viyavleniye osnovnix faktorov pri izuchenii transformatsiy opolznevix massivov yugo-vostochnoy okonechnosti Bolshogo Kavkaza. In: Gidrometeorologiya i ekologiya. Yejekvartalniy Nauchno-Texnicheskiy Jurnal, 4, 132-143.

[6] Zhang, J.P., Zhang, L.B., Liu, W.L., Qi, Y. and Wo, X. (2014) Livestock-Carrying Capacity and Overgrazing Status of Alpine Grassland in the Three-River Headwaters Region, China. Journal of Geographical Sciences, 24, 303-312. http://dx.doi.org/10.1007/s11442-014-1089-z

[7] Fortier, D. (2012) Geomorphology of a Thermo-Erosion Gully, Bylot Island, Nunavut, Canada. Canadian Journal of Earth Sciences, 49, 979-986. 
[8] Gogichaishvili, G.P., Kirvalidze, D.R. and Gorjomeladze, O.L. (2014) Testing of the Hydromechanical Prediction Model of Soil Erosion under the Conditions of Georgia. Eurasian Soil Science, 47, 917-922. http://dx.doi.org/10.1134/S106422931409004X

[9] Chen, C.-Y. (2009) Sedimentary Impacts from Landslides in the Tachia River Basin, Taiwan. Geomorphology, 105, 355-365. http://dx.doi.org/10.1016/j.geomorph.2008.10.009

[10] Mekhtiyev, A.Sh. (1998) Aerokosmicheskiye issledovaniya v Azerbaydjane. In: Materiali vtoroy nauchno-prakticheskoy konferentsii “Azerbaidjan na poroge XXI veka”, Baku, 343-346.

[11] Yastikli, N., Sefercik, U.G. and Esirtgen, F. (2014) Quantitative Assessment of Remotely Sensed Global Surface Models Using Various Land Classes Produced from Lands at Data in Istanbul. Chinese Geographical Science, 24, 307-316. http://dx.doi.org/10.1007/s11769-014-0681-6

[12] Carver, S.J. (1991) Integrating Multi-Criteria Evaluation with Geographical Information Systems. International Journal of Geographical Information Systems, 5, 321-339. http://dx.doi.org/10.1080/02693799108927858

[13] Budagov, B.A., Mamedov, R.M. and Alizade, E.K. (2009) Problemi sbalansirovannogo razviviya ekodinamicheski napryajennix gornix geosistem azerbaydjanskoy chasti Bolshogo Kavkaza. Izvestiya Rossiyskoy Akademii Nauk. Seriya geograficheskaya, 3, 37-41.

[14] Nosenko, G.A., Rototayeva, O.V. and Nosenko, O.A. (2005) Vozmojnosti monitoringa iz kosmosa opasnix glyatsialnix protsessov v trudnodostupnix gornix rayonax (na primere Karmadonskoy katastrofi 2002 g.). Issledovaniye zemli iz kosmosa, 1, 75-81.

[15] Dawson, A.G., Matthews, J.A. and Shakesby, R.A. (1986) A Catastrophic Landslide (Sturzstrom) in Verkilsdalen, Rondane National Park, Southern Norway. Geografiska Annaler. Series A, Physical Geography, 68, 77-87. http://dx.doi.org/10.2307/521178

[16] Nicorici, C., Gray, J., Imbroane, A.M. and Barbosu, M. (2012) GIS Susceptibility Maps for Shallow Landslides: A Case Study in Transylvania, Romania. Carpathian Journal of Earth and Environmental Sciences, 7, 83-92.

[17] Petrea, D., Bilaşkco, Ş., Roşca, S., Vescan, I. and Fodorean, I. (2014) The Determination of the Landslide Occurrence Probability by GİS Spatial Analysis of the Land Morphometric Characteristics (Case Study: The Transylvanian Plateau). Carpathian Journal of Earth and Environmental Sciences, 9, 91-102.

[18] Ayalew, L. and Yamagishi, H. (2005) The Application of GIS-Based Logistic Regression for Landslide Susceptibility Mapping in the Kakuda-Yahiko Mountains, Central Japan. Geomorphology, 65, 15-31. http://dx.doi.org/10.1016/j.geomorph.2004.06.010

[19] Shroder Jr., J.F. and Weihs, B.J. (2010) Geomorphology of the Lake Shewa Landslide Dam, Badakhshan, Afghanistan, Using Remote Sensing Data. Geografiska Annaler. Series A, Physical Geography, 92, 469-483. http://dx.doi.org/10.1111/j.1468-0459.2010.00408.x

[20] Glenn, N.F., Streutker, D.R., Chadwick, D.J., Thackray, G.D. and Dorsch, S.J. (2006) Analysis of LiDAR-Derived Topographic Information for Characterizing and Differentiating Landslide Morphology and Activity. Geomorphology, 73, 131-148. http://dx.doi.org/10.1016/j.geomorph.2005.07.006

[21] Bell, R., Petschko, H., Röhrs, M. and Dix, A. (2012) Assessment of Landslide Age, Landslide Persistence and Human Impact Using Airborne Laser Scanning Digital Terrain Models. Geografiska Annaler: Series A, Physical Geography, 94, 135-156. http://dx.doi.org/10.1111/j.1468-0459.2012.00454.x 